\title{
Natural Fertilizer-Revolution in the Field of Agriculture
}

\author{
Vaidya Rohit Mehta* and Ashutosh Guleri \\ Senior Medical Officer, Himalayan Research Institute for Naturopathy \& Yoga, India
}

*Corresponding author: Vaidya Rohit Mehta, Senior Medical Officer, KAYAKALP(Himalayan Research Institute for Yoga \& Naturopathy), Vivekanand Medical Research Trust, Palampur, Kangra, India

\section{Opinion}

Cow is a blessing to mankind on earth. There are almost 37 types of cows which are predominant in India out of which Sahiwal, Gir and Tharparkar are very famous. Milk, Ghee, Urine and dung of Indian variety of cows is very useful and used for eating, medicine and as a natural fertilizer. Milk of the Indian cow is sweet, cold, soft, unctuous, smooth and increases immunity. This milk contains A2 protein is easily digestible and useful in the prevention of diseases related to the stomach. It contains low amount of cholesterol which prevents heart diseases, diabetes mellitus and cancer. Ghee of India cows increases memory, intellect, digestion and immunity. Urine helps in killing bacteria and in treating leprosy.

In the field of agriculture, they play a very important role and usually the cow dung is used a natural fertilizer which has its own limitations. It only increases the growth of the plant which is also very minimal.

The plant absorbs only 1.5 to $2.0 \%$ of its important ingredients from earth. Rest $98 \%$ are absorbed from air, sun and water.

With the concept of organic farming and natural fertilizer, the farming was brought to the next level by two new formulations used in the field of farming namely "Jiva Amrit" and "Ghan Jiva amrit"

\section{Jiva Amrit}

$\underline{\text { Table } 1}$

\begin{tabular}{|c|c|c|}
\hline \multicolumn{3}{|c|}{ Ingredients of Jiva Amrit } \\
\hline Sl. No & Ingredients & Quantity \\
\hline 1 & Dung of Indian Cows & $10 \mathrm{Kg}$ \\
\hline 2 & Urine of Indian Cows & $5-10 \mathrm{Lit}$ \\
\hline 3 & Jaggery & $1-2 \mathrm{Kg}$ \\
\hline 4 & Bengal Gram Flour & $1-2 \mathrm{Kg}$ \\
\hline 5 & Water & $200 \mathrm{Lit}$ \\
\hline 6 & Mud near to the tree & $1 \mathrm{Kg}$ \\
\hline
\end{tabular}

Jiva amrit is the prepared in the following way-dung and urine of Indian cows, jaggery, Bengal gram floor, water and mud near to the tree is used in the preparation of the Jiva Amrit. All the above ingredients are stored in a vessel and kept for fomentation for 2 to 3 days. This solution should be rotated in a clockwise direction twice in a day and then covered again. Once it gets fermented it releases ammonia, carbon monoxide and carbon dioxide, methane and other gases. This solution is sprinkled over the plants to prevent it from any harmful bacterial infection and increase its production multiple times (Table 1).

\section{Ghan Jiva amrit}

Ghan Jiva amrit is prepared in the following way-dung and urine of Indian cows, jaggery, mud near to the trees and Bengal gram flour are mixed and mashed properly so it becomes like a bolus. This mixture should be covered properly, and small amount of water should be sprinkled on the same for 2 days. Again, this mixture is taken and mashed properly and mixed with the seeds of the plants. This is again made into a bolus along with the seeds and kept on the earth, covered with dry leaves. Water should be sprinkled on the same until plant growth is seen. This helps in supplying the important properties to the plants from its initial growth. The plants grown in this way are usually big in size. It also fastens the growth time of the plant (Table 2).

Table 2

\begin{tabular}{|c|c|c|}
\hline \multicolumn{3}{|c|}{ Ingredients of Ghan Jiva Amrit } \\
\hline Sl. No & Ingredients & Quantity \\
\hline 1 & Dung of Indian Cow & $100 \mathrm{~kg}$ \\
\hline 2 & Jaggery & $1 \mathrm{~kg}$ \\
\hline 3 & Black gram flour & $2 \mathrm{~kg}$ \\
\hline 4 & Mud near to the tree & 100 grams \\
\hline 5 & Urine of Indian cow & $100-500 \mathrm{ml}$ \\
\hline
\end{tabular}

These two modes of growing plants basically focus on organic farming and natural fertilizers. As these fertilizers have better properties then the modern fertilizers like Urea and the amount required in the preparation of this is very minimal so it is modern way of farming with traditional herbs and Zero budget. 
CC (i) This work is licensed under Creative To Submit Your Article Click Here: Submit A ride

DOI: $10.32474 /$ CTBM.2019.01.000113

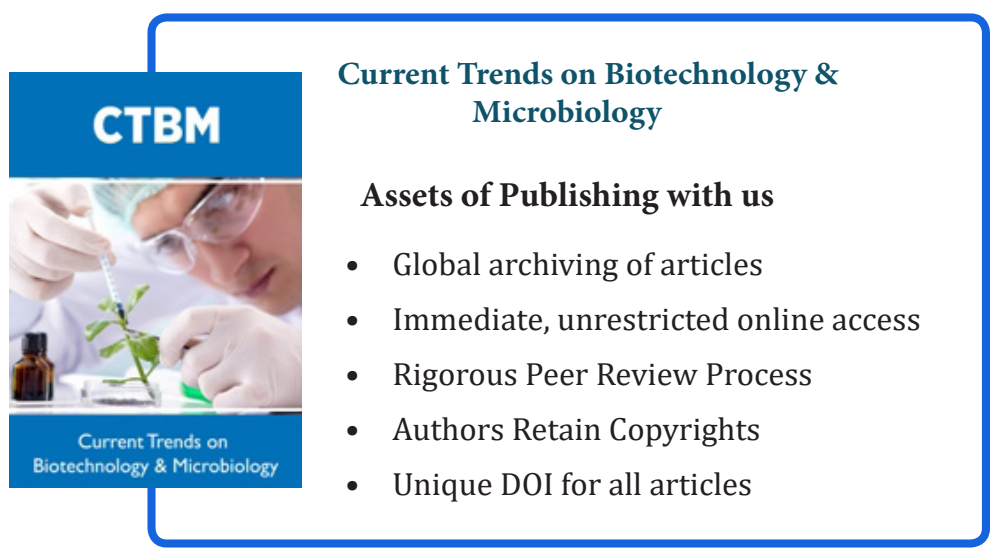

